2020 (114): 95-99.

(C) A szerző(k) 2020

replika.hu/replika/114

\title{
Takács-Sánta András
}

\section{Öhológıaı radılialımus vagy összeomlás}

\begin{abstract}
Absztrakt: Jelen írás reakció Bognár Bulcsu „Az ökológiai kommunikáció lehetőségei és korlátai a modernitásban" című cikkére, amelyben kifejtem, hogy míg Bognár diagnózisa meggyőző (noha részleges) azt illetően, hogy miért nem tudnak társadalmaink megfelelő választ adni az ökológiai válságra, a szerző a diagnózisból következő terápiáig mintha a radikális megoldásokkal szembeni ellenérzései miatt nem jutna el. Bognár írásából hiányzik az a fontos szempont, hogy alapvető ellentét feszül a modernitás kulturális paradigmája és az ökológiai gondolkodásmód között. Ezért is van az, hogy a modernitás társadalmi intézményrendszere nem képes befogadni az igencsak más értékrendbeli és világnézeti alapokon nyugvó ökológiai mozgalmak követeléseit. Mindebből az következik, hogy csak egy új, az ökológiai gondolkodásmódon alapuló társadalmi intézményrendszer fölépítésével tudjuk elkerülni az ökológiai összeomlást.
\end{abstract}

Kulcsszavak: modernitás, társadalmi intézményrendszer, ökológiai gondolkodásmód, ökológiai fenntarthatóság 
Nagyjából fél évszázaddal ezelőtt döbbentünk rá széles körben az ökológiai válságra (McNeill 2000). Ám azóta inkább csak kisebb korrekciókat sikerült elvégeznünk társadalmainkon, azok irányát nem tudtuk olyan mértékben módosítani, hogy a válság fenyegetése legalábbis számottevően enyhüljön. Vajon miért? És hogyan tudnánk ezen változtatni? Ezekkel a létkérdésekkel birkózik inspiráló írásában Bognár Bulcsu, és míg a diagnózisa igen meggyőző (bár már csak a téma hihetetlen komplexitása miatt is kényszerủen részleges), az abból szinte kézenfekvő módon következő terápiáig már nem jut el. Talán azért (sem), mert ezt a terápiát túl radikálisnak érezné - erre utal legalábbis az, hogy már a tanulmány elején kritikusan viszonyul a „zöldek” radikalizmusához. Tartok tőle azonban, hogy az ökológiai válság mélyülésével az opcióink mára kényszerüen leegyszerűsödtek: gyökeres átalakulás és társadalmi összeomlás között választhatunk már csak. Meg kellene tehát barátkoznunk a békés ökológiai radikalizmussal.

Az ökológiai válság folyamatai (az éghajlatváltozás, a talajok pusztulása, az erdőirtások stb.) társadalmi szinten éhínséget, szomjúságot, egészségünk romlását, nyomort, valamint a kimerülőben lévő természeti források birtoklásáért folytatott erőszakos konfliktusokat eredményeznek. Mindez nem pusztán a jövő fenyegetése, a válságban már jó ideje benne vagyunk - még ha egyelőre sokkal inkább a perifériát sújtja is, semmint a centrumot. A trendek az ökológiai összeomlás felé mutatnak, ami leginkább az emberi népességszám drasztikus csökkenését jelentené, továbbá az életben maradók életminőségének jelentős romlását - valahogy úgy, ahogy az már jó pár ökológiai öngyilkosságot elkövető múltbeli társadalommal, például a Húsvét-sziget népével történt (Diamond 2005). Az összeomlás ugyanakkor a legtöbbek szerint még elkerülhető volna, és ezért ma már számos kezdeményezés küzd társadalmainkban.

Bognár Bulcsu alaposan és meggyőzően elemzi, hogy az ő követeléseik miért pattannak vissza újra és újra a modern társadalom maguk racionalitása szerint működő részrendszereiről, azok miért nem fogékonyak az ökológiai racionalitásra. Tanulmányából ugyanakkor kimarad egy nagyon fontos szempont, mégpedig az, hogy mindez egy csöppet sem meglepő, mivel a modern társadalom felépítménye még jócskán az ökológiai válság széles körű tudatosulása előtt alakult ki, és természetesen a modernitás gondolkodásmódját (értékrendjét és világnézetét) tükrözi. Csakhogy az ökológiai gondolkodásmód sarkalatos pontokon megy szembe homlokegyenest a modernitás kulturális paradigmájával, vagyis szembehelyezkedik annak néhány alapvető meggyőződésével (lásd például Dunlap et al. 2000; Takács-Sánta 2007): többek között az emberiség történelmét határozott irányt nélkülöző változásnak tételezi, semmint folyamatos fejlődésnek; a technikát kétélü fegyvernek gondolja, semmint az emberiség megváltójának; az ember lehetőségeit pedig korlátosnak, méghozzá olyannyira, hogy egyes, például ökológiai korlátokba már bele is ütköztünk - vagyis a határ korántsem a csillagos ég számunkra. ${ }^{1}$

A gyökeresen új meggyőződéseket nyújtó ökológiai gondolkodásmód nem lehet kompatibilis a régi társadalmi intézményrendszerrel, egy attól alapvetően különböző társadalmi berendezkedésnek kellene tartoznia hozzá. A modern társadalom intézményrendszere tehát nem toldozgatható-foltozgatható úgy, hogy eredményes választ tudjon adni az ökológiai válság kihívására. Ha a „részrendszerek racionalitása” nem íródik fölül, akkor legfeljebb annyit

1 A modernitás gondolatvilágát hűen tükrözi Pauwels: „A holnap pedig a szuperemberé, aki úrrá lesz a csillagokon” (1979: 98). (És írásából az tűnik ki, hogy ezt teljesen komolyan is gondolta.) 
érhetünk el, hogy ideig-óráig elodázzuk az összeomlást. Különösen fontos ezt látni a gazdasági rendszer esetében, mivel a környezeti problémákért közvetlenül a gazdasági folyamatok (kitermelés, termelés, fogyasztás) okolhatók (Takács-Sánta 2017: 3. fejezet). Azt a gazdasági rendszert, amely a profit folyamatos növelésén, és így a termelés-fogyasztás állandó bővítésén alapszik, vagyis nem vesz tudomást arról, hogy máris beleütköztünk az ökológiai korlátokba, egyszerüen lehetetlen kizöldíteni. A profitközpontú gazdaság összeegyeztethetetlen az ökológiai fenntarthatósággal (Lux 2003).

Mindez még véletlenül sem jelenti azonban a teljes modernitás szemétdombra hajítását. Ez dőreség volna, hiszen a modernitás jó pár eleme az ökológia szemszögéből is értékes, és így megőrzendő. Mégis egy lényegileg új gondolkodásmód alapján kellene fölépítenünk egy teljesen új társadalmi berendezkedést. Ehhez mindenképp érdemes volna fölhasználni a modernitás néhány gondolati elemét és intézményét is (többek között emberi jogi és demokratikus vívmányokat), ahogy jó néhány premodern gondolati elemet és intézményt szintúgy, ${ }^{2}$ bár leginkább a mai ökologikus szubkultúrákra kellene alapozni az új felépítményt. Mindez azt jelenti, hogy az ökológia egyidejüleg felforgató és konzervatív (Hardin 1985). Árnyalt radikalizmus ez tehát (ha úgy tetszik, konzervatív radikalizmus, és nem, ez itt most nem oximoron), ám mégiscsak a modernitás meghaladására van szükség. Bognár Bulcsu idáig nem jut el, és nagyon úgy tünik, hogy - Luhmann-nal és persze még sokakkal másokkal egyetértésben - egy kizöldült modernitásban hisz. ${ }^{3}$

Mindazok számára viszont, akik még bíznak abban, hogy az ökológiai katasztrófa elkerülhető, ${ }^{4}$ de egyúttal a modernitás kudarcát is belátták, nem igazán maradt más út, mint az, hogy megkíséreljenek alulról indulva fölépíteni egy az ökológiai gondolkodásmódon alapuló új társadalmi rendszert. Ez pedig aligha lehetséges másként, mint hogy az ökológiai fordulat megvalósítására törekvő emberek összefognak, és sok kis helyi, elsősorban közösségi kezdeményezés keretében elkezdik együtt kifaragni ennek az új rendszernek az építőkockáit (Takács-Sánta 2017, 2019): permakultúrás elveken alapuló mezőgazdasági rendszereket, bevásárlóközösségeket, adományboltokat, helyi pénzrendszereket, energiaszövetkezeteket, alternatív iskolákat stb. hoznak létre. Itthon is számos ilyen kezdeményezés müködik már (Takács-Sánta és mtsai 2017). ${ }^{5}$ Ha ezek az új intézmények kicsiben életképesnek és vonzónak bizonyulnak, akkor mintáik terjedni fognak, és fölépülhet egy új társadalmi berendezkedés. Tágabban pedig egy a modernitást meghaladó új kultúra. ${ }^{6}$

Egy ilyen új kultúrának a kialakítása természetesen cudar nehéz feladat, és egyáltalán nem is biztos, hogy az ökológia valaha is domináns társadalmi paradigmává válik majd, túllépve a szubkulturális kereteken. Sőt a jelenlegi trendeket figyelve nagyobb esély látszik ennek ellenkezőjére - ami ma is jó okot ad számos kishitű avagy cinikus vélekedés megfogalmazására. Mégis mindenkinek, aki szereti az életet (akár a sajátját, akár más emberekét, akár

2 Ilyen lehet például az ártéri gazdálkodás egy speciálisan Kárpát-medencei formájának, a kora újkorban nem kis részben hatalmi érdekek nyomán letünt fokgazdálkodásnak az újraélesztése (Andrásfalvy 2000).

3 Az idekapcsolódó műveit döntően az 1980-as, 1990-es években elkövető Luhmann kritikája az ökológiai radikalizmussal szemben akkoriban még alighanem inkább védhető volt, mint manapság. Nem vitatom, hogy Luhmann sok gondolata még ma is érvényes, ám az ökológiai radikalizmus bírálatát az elmélyülő ökológiai válság valósága egyre inkább érvénytelenné teszi.

4 A katasztrofista hozzáállás szerint az ökológiai összeomlás már elkerülhetetlen, és ráadásul nagyon hamar be is fog következni. Ennek a hozzáállásnak éles és elég részletes kritikáját adja Takács-Sánta (2016).

5 Lásd még www.kiutak.hu.

6 Kultúra alatt a társadalmi intézményrendszer és a hozzákapcsolódó gondolkodásmód együttesét értem. 
más élőlényekét), akinek alapvető fontosságú az élet schweitzeri értelemben vett tisztelete (Schweitzer 1966), az esélyektől függetlenül törekednie kell arra, hogy az összeomlást elkerülve minél kisebb megrázkódtatással jussunk el egy új, ökologikus kultúráig.

Bognár Bulcsu szerint Magyarországon az alulról jövő kezdeményezések túl gyengék az ökológiai érdekérvényesítéshez, és csak a „felülről szervezett hierarchia” (Bognár 2020: 31, 32) segítségével működhetnek hatásosan. Ez a megfogalmazás tartalmaz igazságot, ám túlzottan sarkos és leegyszerűsítő. Egyrészt minden alulról induló kezdeményezésnek nyilvánvalóan jót tesz, ha megtámogatják fölülről. Másrészt kétségtelen az is, hogy itthon nehezebb dolguk van az ilyen, alulról szerveződő kezdeményezéseknek, mint tölünk nyugatra. Ám ez nem azt jelenti, hogy le kellene mondaniuk róluk, ha nem kapnak az állam szintjéről támogatást. ${ }^{7}$ Érkezhet segítség számukra ugyanis a civil, sőt az akadémiai szférából is (például a mi munkacsoportjaink is erre törekszenek a Kisközösségi Program elnevezésű kutatási és akcióprogram keretein belül - Takács-Sánta $2020^{8}$ ), de ugyanúgy a települési önkormányzatok részéről is. 2019 ősze óta különösen elmondható, hogy kis falvaktól nagyvárosokig jó néhány hazai településen állt föl olyan önkormányzati testület, amely fontosnak tartja az ökológiai gondolatot, és rokonszenvezik az alulról jövő ökokezdeményezésekkel. Sőt kutatócsoportunk máris találkozott olyan esetekkel is, amikor az önkormányzat egy helyi ökoközösség hóna alá nyúlt.

A fentiekből talán a legfontosabb az, hogy bennünket már csak egy (békés) forradalom menthet meg. Ám ez az ökológiai forradalom nem a múlt végleges eltörléséről szól, hanem éppen arról, hogy annak tanulságait és az emberiség gyökeresen új léthelyzetében is megőrzendőnek gondolt vívmányait egy teljesen új kultúrába kell beépítenünk. Ez a program talán még konzervatív gondolkodók számára is tetszetős lehet.

\section{Hivatkozott irodalom}

Andrásfalvy Bertalan (2000): Ártereink múltja és jövője. In A természet romlása, a romlás természete. Gadó György Pál (szerk.). Budapest: Föld Napja Alapítvány, 60-66.

Bognár Bulcsu (2020): Az ökológiai kommunikáció lehetőségei és korlátai a modernitásban. Társadalomelméleti észrevételek a környezetvédelem témájához. Replika (114): 7-39. DOI: https://doi.org/10.32564/114.1

Diamond, Jared (2005): Collapse: How Societies Choose to Fail or Succeed. New York: Viking Press. (Magyarul: Összeomlás - Tanulságok a társadalmak továbbéléséhez. Budapest: Typotex, 2007.)

Dunlap, Riley E. et al. (2000): Measuring Endorsement of the New Ecological Paradigm: A revised NEP scale. Journal of Social Issues (56): 425-442.

Hardin, Garrett (1985): Human Ecology: The Subversive, Conservative Science. American Zoologist (25): 468-476.

Lux, Kenneth (2003): The Failure of the Profit Motive. Ecological Economics (44): 1-9. (Magyarul: A profitérdekeltség kudarca. Kovász 10[1-4]: 7-20.)

McNeill, John R. (2000): Something New Under the Sun: An Environmental History of the Twentieth Century. New York: W. W. Norton and Company. (Magyarul: Valami új a nap alatt - A huszadik század környezettörténete. Budapest: Ursus Libris, 2011.)

Pauwels, Louis (1979): Ökománia. Interpress Magazin (8): 96-98.

Schweitzer, Albert (1966): Ma Vie et ma Pensée. Paris: Albin Michel. (Magyarul: Életem és gondolataim. Budapest: Gondolat, 1974.)

Takács-Sánta András (szerk.) (2007): Paradigmaváltás?! - Kultúránk néhány alapvető meggyőződésének újragondolása. Budapest: L'Harmattan.

7 Csak sejtem persze, hogy a szerző főként erre gondol, amikor a „felülről szervezett hierarchia” támogatásáról beszél. 8 Lásd még www.kiskozossegek.hu. 
Takács-Sánta András (2016): Mit szóljunk ahhoz, hogy süllyed a hajónk? Négyféle hozzáállás kultúránk válságához. In Ökológiai lábnyom és fenntarthatatlanság. Horváth B. (szerk.). Budapest: L’Harmattan, 239-244.

Takács-Sánta András (2017): A közlegelők komédiája - A közösségek újrafelfedezése mint kiút az ökológiai válságból. Budapest: L'Harmattan.

Takács-Sánta András (2019): Kisközösségek békés ökoforradalma. Ellensúly (2): 87-95.

Takács-Sánta András (2020): Próféták és helyi ökoközösségek - A Kisközösségi Program és az Új Koma Háló. Máltai Tanulmányok 2(1): 127-142.

Takács-Sánta András és munkatársai (2017): Építőkockák egy új világhoz - Ökológia, közösség, boldogulás - helyben! Budapest: Andron Könyv Kft. - Kisközösségi Program.

\section{Takács-Sánta András}

Humánökológus, ELTE TÁTK Empirikus Tanulmányok Intézete és ELTE TTK Környezettudományi Centrum (Budapest) 
